\title{
pVHL is a regulator of glucose metabolism and insulin secretion in pancreatic $\beta$ cells
}

\author{
Jens Zehetner, ${ }^{1}$ Carsten Danzer, ${ }^{1,5}$ Stephan Collins, ${ }^{2,5}$ Katrin Eckhardt, ${ }^{1}$ Philipp A. Gerber, ${ }^{1}$ \\ Pia Ballschmieter, ${ }^{1}$ Juris Galvanovskis, ${ }^{2}$ Kenju Shimomura, ${ }^{3}$ Frances M. Ashcroft, ${ }^{3}$ \\ Bernard Thorens, ${ }^{4}$ Patrik Rorsman, ${ }^{2}$ and Wilhelm Krek ${ }^{1,6}$ \\ ${ }^{1}$ Institute of Cell Biology and Competence Center for Systems Physiology and Metabolic Diseases, ETH Zurich, 8093 \\ Zurich, Switzerland; ${ }^{2}$ Oxford Centre for Diabetes, Endocrinology, and Metabolism, Churchill Hospital, Oxford OX3 7LJ, \\ United Kingdom; ${ }^{3}$ Henry Wellcome Centre for Gene Function, Department of Physiology, Anatomy, and Genetics, \\ University of Oxford, Oxford OX1 3PT, United Kingdom; ${ }^{4}$ Department of Physiology and Center for Integrative Genomics, \\ University Lausanne, 1015 Lausanne, Switzerland
}

Insulin secretion from pancreatic $\beta$ cells is stimulated by glucose metabolism. However, the relative importance of metabolizing glucose via mitochondrial oxidative phosphorylation versus glycolysis for insulin secretion remains unclear. von Hippel-Lindau (VHL) tumor suppressor protein, pVHL, negatively regulates hypoxia-inducible factor $\mathrm{HIF} 1 \alpha$, a transcription factor implicated in promoting a glycolytic form of metabolism. Here we report a central role for the pVHL-HIF1 $\alpha$ pathway in the control of $\beta$-cell glucose utilization, insulin secretion, and glucose homeostasis. Conditional inactivation of Vhlh in $\beta$ cells promoted a diversion of glucose away from mitochondria into lactate production, causing cells to produce high levels of glycolytically derived ATP and to secrete elevated levels of insulin at low glucose concentrations.

Vhlh-deficient mice exhibited diminished glucose-stimulated changes in cytoplasmic $\mathrm{Ca}^{2+}$ concentration, electrical activity, and insulin secretion, which culminate in impaired systemic glucose tolerance.

Importantly, combined deletion of Vhlh and Hif1 $\alpha$ rescued these phenotypes, implying that they are the result of HIF1 $\alpha$ activation. Together, these results identify pVHL and HIF1 $\alpha$ as key regulators of insulin secretion from pancreatic $\beta$ cells. They further suggest that changes in the metabolic strategy of glucose metabolism in $\beta$ cells have profound effects on whole-body glucose homeostasis.

[Keywords: HIF; VHL; glucose intolerance; islet; pancreas]

Supplemental material is available at http://www.genesdev.org.

Received July 14, 2008; revised version accepted September 5, 2008.

During adulthood, cell type-specific growth that exceeds the normal physiological constraints is a common feature of adaptive processes of tissues to changes in metabolic homeostasis and underlies the development of many human diseases, including cancer, heart disease, and diabetes (De Boer et al. 2003; Bouwens and Rooman 2005). Adaptive cell mass expansion, whether neoplastic or nonneoplastic, creates a requirement for compensatory neovascularization to supply oxygen, metabolic substances, and growth/survival factors to the growing tissue (Marti 2005). Therefore, adaptive cell growth responses are generally accompanied, at least initially, by relative states of hypoxia as a result of a mismatch between oxygen demand caused by tissue expansion and

${ }^{5}$ These authors contributed equally to this work.

${ }^{6}$ Corresponding author.

E-MAIL wilhelm.krek@cell.biol.ethz.ch; FAX 41-44-633-1357.

Article is online at http://www.genesdev.org/cgi/doi/10.1101/gad.496908. oxygen supply provided by the vasculature. An immediate consequence of decreased tissue oxygen availability is that cells shift cellular fuel metabolism from mitochondrial respiration to glycolysis and activate an angiogenic program to increase oxygen delivery in order to overcome the imbalance between tissue mass and vascularization (Semenza 2001; Brahimi-Horn et al. 2007). In this way, tissue function is supported and further mass expansion can occur.

At the molecular level, the central regulators of the cellular response to low-oxygen availability are the hypoxia-inducible transcription factors (HIF). HIF are heterodimeric transcription factors composed of $H I F 1 \alpha$, HIF2 $\alpha$, or HIF3 $\alpha$ (collectively HIF $\alpha$ ) and HIF $\beta /$ ARNT (Aryl hydrocarbon receptor nuclear translocator) subunits. While the latter is constitutively expressed and stable, HIF $\alpha$ subunits are rapidly degraded under normoxia due to prolylhydroxylase activity, which marks them for recognition by the von Hippel-Lindau (VHL) tumor suppressor ubiquitin ligase complex, targeting 
them for ubiquitination and proteasomal degradation (Schofield and Ratcliffe 2004). Hypoxia leads to a stabilization of $\mathrm{HIF} \alpha$, dimerization with constitutively expressed HIF $\beta / A R N T$ subunits, and the activation of hypoxia-inducible genes, whose products play key roles in the regulation of diverse processes including angiogenesis, glucose uptake, and the conversion of cellular metabolism from a mitochondrial oxidative toward a glycolytic form of ATP production (Fantin et al. 2006; Kim et al. 2006; Papandreou et al. 2006). There is evidence to suggest that HIF $1 \alpha$ preferentially activates genes important for glycolysis, while HIF2 $\alpha$ favors genes involved in angiogenesis (Hu et al. 2003; Rankin et al. 2008). Finally, in addition to the well-established activation of HIF $\alpha$ in response to oxygen availability, there is accumulating evidence for hypoxia-independent mechanisms of HIF $1 \alpha$ expression. For example, high levels of HIF $1 \alpha$ expression have been observed under well-oxygenated conditions in response to growth factor stimulation (Hellwig-Burgel et al. 2005). Growth factor-mediated up-regulation of HIF $1 \alpha$ expression has been implicated to promote glucose uptake and a form of metabolism that is referred to as "aerobic glycolysis" to better meet the bioenergetic needs associated with growth and proliferation (Lum et al. 2007).

Pancreatic $\beta$ cells display significant plasticity in response to changes in metabolic homeostasis (Bouwens and Rooman 2005). The mass of $\beta$ cells is known to increase during pregnancy, to compensate for the increased metabolic load of a developing fetus (Van Assche et al. 1978), and in nondiabetic obese individuals, as part of an adaptive response to increased metabolic load and obesityassociated insulin resistance (Prentki and Nolan 2006), thereby maintaining a balance between metabolic demand and insulin supply. Conversely, when $\beta$ cells fail to respond to the body's insulin demand, type 2 diabetes results (Rhodes 2005). Thus, adaptive changes in functional $\beta$-cell mass is key to maintaining systemic euglycemia.

In this regard, gene expression analysis of prediabetic and diabetic Zucker diabetic fatty (ZDF) rats, which carry a mutation in the leptin receptor gene and serve as a model for $\beta$-cell mass adaptation and decompensation during progression of type 2 diabetes, revealed that certain hypoxia-inducible target genes become activated at the prediabetic stage, coinciding with adaptive $\beta$-cell mass expansion (Li et al. 2006). The hypoxia-inducible genes that are activated include those whose products influence glycolysis, such as lactate dehydrogenase A (LDHA) that catalyzes the conversion of pyruvate to lactate, as well as angiogenesis, such as vascular endothelial growth factor (VEGF) that is known to be critical for $\beta$-cell function (Lammert et al. 2003). These data highlight the importance of $\beta$-cell expansion being accompanied by adaptive changes of the vascular supply of oxygen.

The intimate link between decreased tissue oxygen availability and changes in glucose metabolism implies a potential role for the HIF system in $\beta$-cell metabolism, and hence, insulin secretion. Here we explore the physiological role of the HIF system in insulin secretion using mouse models in which the Vhlh and Hif1 $\alpha$ genes are conditionally inactivated (singly or in combination) in $\beta$ cells. Our results suggest that HIFl $\alpha$ activation mediates metabolic reprogramming of $\beta$ cells to a glycolytic form of ATP production, causing a switch from regulated to constitutive increased basal and impaired glucose-stimulated insulin secretion, hallmarks of type 2 diabetes.

\section{Results}

Deletion of Vhlh leads to the accumulation of transcriptionally active HIF1 $\alpha$ in $\beta$ cells

The mRNAs of Vhlh and Hif1 $\alpha$ are highly enriched in islets of wild-type $(\mathrm{wt})$ mice (hereafter referred to as control) compared with total pancreas as evidenced by realtime PCR analysis (Fig. 1A). Also, the heterodimerization partner of Hif1 $\alpha$, Hif1 $\beta /$ ARNT, is expressed in pancreatic $\beta$ cells (Supplemental Fig. S1). In addition, confocal immunofluorescence (IF) microscopy demonstrated that pVHL colocalizes predominantly with the insulin-producing $\beta$ cells (Fig. 1B). ARNT colocalizes as well with $\beta$ cells (Supplemental Fig. S1). Thus, Vhlh, $H i f 1 \alpha$, and Arnt are principally expressed in mouse islets. To investigate the physiological effects of Vhlh deletion in pancreatic $\beta$ cells, mice with a loxP-flanked Vhlh allele were crossed to Rip2-Cre transgenic mice carrying the Cre-recombinase under the rat insulin promoter (Herrera 2000). This transgene induces Cre-mediated recombination specifically in pancreatic $\beta$ cells. Deletion of Vhlh in pancreatic islets of Rip2-Cre; Vhlh ${ }^{\mathrm{fl} / \mathrm{fl}}$ mice (hereafter referred to as $V h l h^{-1-}$ ) was confirmed by PCR-mediated detection of the recombined Vhlh allele, as identical sized bands were generated by these PCR reactions as from kidney DNA derived from a kidneyspecific $\mathrm{Vhlh}^{-1-}$ mouse model (Fig. 1C; Frew et al. 2008). Immunohistochemical analysis of islets of 26 -wk-old $V h l h^{-1-}$ mice revealed strong nuclear accumulation of HIF1 $\alpha$ (Fig. 1D, insert). High levels of the HIF $\alpha$ target protein glucose transporter 1 (SLC2A1; also referred to as GLUT1) were also observed (Fig. 1D). Neither the overall morphology nor staining for insulin or glucagon was detectably affected by deletion of Vhlh (Fig. 1D). Immunoblotting of purified islets of $\mathrm{Vhlh}^{-/-}$mice confirmed that $V h l h$ was efficiently deleted and that HIF $1 \alpha$ and SLC2A1 levels were increased (Fig. 1E). These results suggest that deletion of Vhlh in pancreatic $\beta$ cells leads to the accumulation of HIFl $\alpha$ and target genes.

To assess whether the activation of hypoxia-inducible genes such as S1c2a1 is HIF1 $\alpha$-dependent, we used mice with a loxP-flanked $H$ if $1 \alpha$ allele $\left(H i f 1 \alpha^{\mathrm{fl} / \mathrm{fl}}\right)$ to generate Rip2-Cre; Hif1 $\alpha^{\mathrm{fl} / \mathrm{fl}}$ mice (hereafter referred to as Hif1 $\alpha^{-/-}$) and Rip2-Cre; Vhlh ${ }^{\mathrm{fl} / \mathrm{fl}} ; \mathrm{Hif1} \alpha^{\mathrm{fl} / \mathrm{fl}}$ (hereafter referred to as $V h l h^{-/-} H i f 1 \alpha^{-/-}$) mice, in which Hif1 $\alpha$ was deleted in a control or Vhlh mutant background, respectively. $\beta$-cellspecific deletion of either Hif1 $\alpha$ alone or in combination with Vhlh was confirmed by PCR-mediated detection of the corresponding recombined alleles using tail DNA as control (data not shown). At 26 wk of age, Hif1 ${ }^{-/-}$and 
A
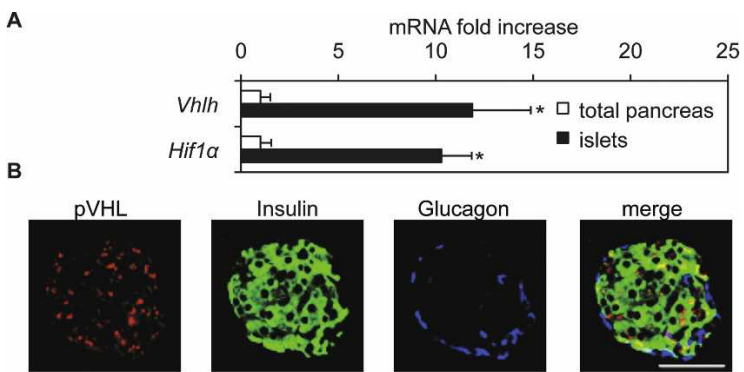

C
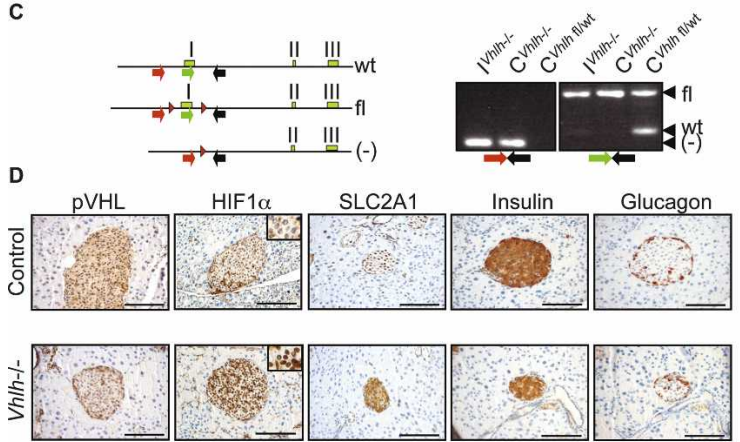

E

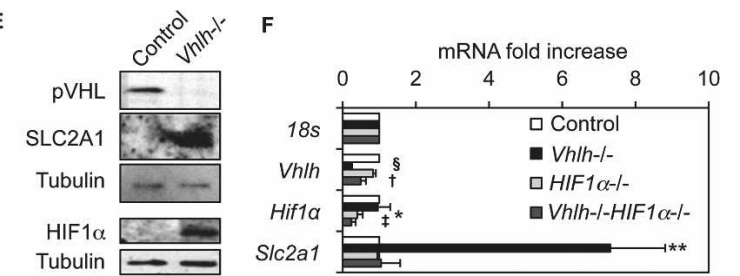

Figure 1. Expression of Vhlh and Hif1 $\alpha$ in pancreatic mouse islets and the analysis of $\beta$-cell-specific $\mathrm{Vhlh}^{-/-}, \mathrm{Hifl}^{-/-}$, and Vhlh ${ }^{-/-} H$ if $1 \alpha^{-/-}$mice. (A) Real-time PCR analysis of pancreatic islets versus total pancreas of wild-type (wt) mice ( $n=3$ mice). $\left({ }^{\star}\right) P<0.05$ (Student). $(B)$ Confocal images of wild-type pancreatic islets stained for $\mathrm{pVHL}$, insulin, and glucagon (bar, $50 \mu \mathrm{m}$; $n=3$ mice). (C) PCR analysis of recombination at the Vhlh locus in mice. The positions of the bands representing the Vhlh-floxed (fl), wild-type (wt), and recombined (-) alleles are indicated. Arrows (red, green, and black) mark the primers used for detection. Islet DNA of $\mathrm{Vhlh}^{-/-}$islets $\left(\mathrm{I}^{\mathrm{Vhlh}^{-1-}}\right)$ was compared with kidney DNA of a kidney-specific $\mathrm{Vhlh}^{-/-}$mouse model (positive control: $\mathrm{C}^{\text {Vhlh }^{-1-}}$; negative control: $\mathrm{C}^{\mathrm{Vhlh}^{\mathrm{f} / \mathrm{wt}}}$ ) (Frew et al. 2008). (D) IHC using pancreatic sections of control mice and conditional $V h l h^{-1-}$ mice (bar, $100 \mu \mathrm{m} ; n=3$ mice). (E) Immunoblotting for pVHL, SLC2A1, and HIF $1 \alpha$ using isolated islets of control versus $\mathrm{Vhlh}^{-1-}$ mice $(n=2$ mice). (F) RNA expression levels of Vhlh, Hif1 $\alpha$, and the HIF target glucose transporter 1 (Slc2a1) of control, Vhlh ${ }^{-/-}$, Hif $1 \alpha^{-/-}$, and Vhlh ${ }^{-/-} \mathrm{Hif}_{1 \alpha^{-/-}}$mice $(n=3$ each genotype). 18S RNA levels were used for normalization. (§) $P<0.005 \mathrm{Vhlh}^{-/-}$versus control and $\mathrm{Hifl}^{-/-} ;$(t) $\mathrm{P}=0.004$ Vhlh ${ }^{-/-} \mathrm{Hifl}^{-/-}$versus control, $P=0.031 \mathrm{Vhlh}^{-/-} \mathrm{Hifl}^{-/-}$versus Hif1 $\alpha^{-/-}$; (*) $P=0.047 \mathrm{Hif1} \alpha^{-/-}$versus control; (¥) $P=0.017$ Vhlh $^{-1-} \mathrm{Hifl}^{-/-}$versus control, $\mathrm{P}=0.022 \mathrm{Vhlh}^{-1-} \mathrm{Hifl}^{-/-}$versus Vhlh $^{-/-}$(all Fisher LSD); $\left.{ }^{\star \star}\right) P<0.05$ Vhlh $^{-/-}$versus all groups (Student-Newman-Keuls).

Vhlh ${ }^{-/}$Hif $1 \alpha^{-/-}$mice showed normal islet morphology and unchanged insulin and glucagon staining (data not shown). Further statistical analysis of pancreatic sections demonstrated no significant changes in islet mass

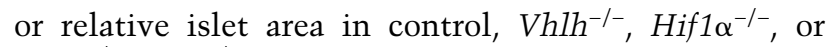
$\mathrm{Vhlh}^{-/-} \mathrm{Hif} 1 \alpha^{-/-}$mice (Table 1). In addition, islet as well as $\beta$-cell size was similar in all genotypes. Interestingly, $\beta$-cell density (the amount of $\beta$ cells per area pancreas) was significantly decreased in $V h l h^{-/-}$mice. This decrease in $\beta$-cell density in $\mathrm{Vhlh}^{-/-}$mice was further augmented in 52-wk-old mice (data not shown), implying that the long-term end product of Vhlh deficiency is reduced $\beta$ cell mass. At the molecular level, combined deletion of Vhlh and Hif1 $\alpha$ prevented the accumulation of S1c2a1 mRNAs that occurred in islets of $\mathrm{Vhlh}^{-/-}$mice (Fig. 1F), supporting the view that Slc2a1 gene activation is HIF $1 \alpha$-mediated.

HIF1 $\alpha$ activation promotes glycolysis and robust ATP production at low glucose

To further investigate the gene expression changes associated with Vhlh deficiency, we performed microarray analysis with RNA isolated from control or $\mathrm{Vhlh}^{-/-}$islets. These data revealed that the majority of genes whose products function in glycolysis were dramatically up-regulated in $V_{h l h}{ }^{--}$mice (Supplemental Fig. S2). Real-time PCR analysis showed that the up-regulation of the glycolytic genes in $V h l h^{-/-}$mice primarily depends on $\mathrm{HIFl} \alpha$, as no such increase was seen in the Vhlh ${ }^{-/} H$ if $1 \alpha^{-/-}$mice (Fig. 2A, top panel). Importantly, increased levels of pyruvate dehydrogenase $(P d h)$ kinase $(P d k) 1$ and Ldha mRNA were also observed in $V h l h^{-/-}$mice in a HIF1 $\alpha$-dependent manner (Fig. 2A, bottom panel). PDK1 phosphorylates and thereby inactivates $\mathrm{PDH}$, the enzyme that converts pyruvate into acetyl-CoA for entry into the mitochondrial tricarboxylic acid (TCA) cycle, while LDHA converts pyruvate into lactate. Immunoblotting of lysates of purified islets isolated from $\mathrm{Vhlh}^{-/-}$, Hif $1 \alpha^{-/-}$, or $\mathrm{Vhlh}^{-/-} \mathrm{Hif} 1 \alpha^{-/-}$ mice demonstrated a high level of PDK1 and LDHA protein production in $\mathrm{Vhlh}^{-/-}$, but not $\mathrm{Vhlh}^{-/-} \mathrm{Hifl}^{-/-}$mice (Fig. 2B).

Since the expression of PDK1 and LDHA was increased, the data suggest that HIF $1 \alpha$ transcription activity reprograms the utilization of available glucose from mitochondrial oxidative phosphorylation to glycolysis to maintain a high rate of glycolytic ATP production. Indeed, islets of $\mathrm{Vhlh}^{-/-}$mice displayed a higher glycolytic rate at $5 \mathrm{mM}$ glucose and secreted significantly more lactate when compared with islets from $\mathrm{Vhlh}^{-/-} \mathrm{Hif1 \alpha ^{-/- }}$ mice (Fig. 2C,D, respectively). Vhlh ${ }^{-/}$islets had higher levels of ATP under low glucose conditions than the corresponding islets of $\mathrm{Vhlh}^{-/-} \mathrm{Hif1 \alpha ^{-/- }}$, Hif $1 \alpha^{-/-}$, or control mice (Fig. 2E), reaching ATP levels similar to those provided with $20 \mathrm{mM}$ glucose. This indicates that ATP production in $\mathrm{Vhlh}^{-/}$islets is independent of the ambient glucose levels.

\section{Vhlh-deficient mice display impaired glucose} tolerance

As insulin secretion from $\beta$ cells is dependent on a rise in cellular ATP levels generated by glucose-stimulated 
Table 1. Statistical analysis of pancreatic sections

\begin{tabular}{|c|c|c|c|c|}
\hline & $\begin{array}{c}\text { Control } \\
(n=5)\end{array}$ & $\begin{array}{l}V_{h l h}^{-/-} \\
(n=5)\end{array}$ & $\begin{array}{c}V_{h l h^{-/-} H i f 1 \alpha^{-/-}} \\
\quad(n=3)\end{array}$ & $\begin{array}{l}H i f 1 \alpha^{-/-} \\
(\mathrm{n}=3)\end{array}$ \\
\hline Islet area/Pancreas area (percent) & $2.17 \pm 0.78$ & $1.55 \pm 0.56$ & $1.55 \pm 0.78$ & $2.10 \pm 0.23$ \\
\hline Islet mass (milligrams) & $5.51 \pm 2.05$ & $3.96 \pm 2.16$ & $4.01 \pm 1.69$ & $4.56 \pm 0.42$ \\
\hline Islet area (square microns) & $26,007 \pm 5648$ & $22,289 \pm 8097$ & $20,320 \pm 6950$ & $22,030 \pm 676$ \\
\hline$\beta$-cell area (square microns) & $344 \pm 60$ & $384 \pm 51$ & $380 \pm 55$ & $372 \pm 35$ \\
\hline$\beta$-cell density (cells per square millimeter) & $70.5 \pm 25.6$ & $39.6 \pm 11.9^{\star}$ & $58.9 \pm 19.0$ & $62.6 \pm 21.4$ \\
\hline
\end{tabular}

(*) $P<0.05$ control versus $V_{h l h}{ }^{--}$(Student).

mitochondrial metabolism (Maechler and Wollheim 2001), we next determined the consequences of altered glucose metabolism in $\mathrm{Vhlh}^{-1-}$ mice on glucose homeostasis and tolerance. Plasma glucose level measurements of fed and fasted control or $\mathrm{Vhlh}^{-/-}$mice revealed no significant differences in glucose levels at 8 and 16 wk of age (Fig. $3 \mathrm{~A})$. However, at $26 \mathrm{wk}$ and, even more prominently, at 36 wk of age, $V h l h^{-/-}$mice became hypoglycemic. At 26 wk, differences were detectable only in the fed animals, whereas at $36 \mathrm{wk}$, lower blood glucose levels became apparent in both fasted as well as in random fed animals (Fig. 3A). However, hypoglycemia was not evident in Hif $1 \alpha^{-/-}$and Vhlh $^{-/-} H$ if $1 \alpha^{-/-}$mice. Consistent with this finding, the HbAlc levels, a measure of long-term glycemia, were also lower in $V h l h^{-/-}$mice compared with the other genotypes (Fig. 3B). These results imply that increased levels of HIF1 $\alpha$ promote, in the long-term, a state of hypoglycemia.

Surprisingly, when challenged with high glucose during an intraperitoneal glucose tolerance test (GTT), both male and female $\mathrm{Vhlh}^{-/-}$mice at $20 \mathrm{wk}$ of age exhibited glucose intolerance that was rescued by combined deletion with Hif1 $\alpha$ (Fig. 3C,D, respectively). The glucose intolerance of male and female $\mathrm{Vhlh}^{-/-}$mice was not a consequence of insulin resistance of peripheral tissue, as their response to insulin remained unaltered (Fig. 3E,F). These data suggest that the delayed clearance of glucose from the blood in $\mathrm{Vhlh}^{-1-}$ mice is HIFl $\alpha$-dependent and the result of abnormal insulin secretion from $\mathrm{Vhlh}^{-1-} \beta$ cells. To exclude any influence of Cre-recombinase, also Rip2-Cre; Vhlh ${ }^{\mathrm{wt} / \mathrm{fl}}\left(V h l h^{\mathrm{wt} /-}\right)$ animals were tested in these assays, but such mice did not display altered glucose and altered insulin tolerance (data not shown).

\section{$\beta$ cells of Vhlh-deficient mice display abnormal basal} and glucose-stimulated insulin secretion

To examine insulin secretion profiles in $V h l h^{-1-}$ mice, we first measured blood insulin levels in $\mathrm{Vhlh}^{-/-}$and
Figure 2. Deletion of Vhlh leads to a switch in the metabolic strategy of $\mathrm{Vhlh}^{-1-} \beta$ cells. (A) Real-time PCR analysis of glycolytic genes using RNA of control, Vhlh ${ }^{-/-}$, Hif $1 \alpha^{-1-}$, and Vhlh ${ }^{-1-}$ Hif1 $1 \alpha^{-/-}$mice $(n=3$ each genotype): Glucokinase (Gck), glucosephosphate isomerase 1 (Gpi1), phosphofructokinase, liver (Pfkl), aldolase $\mathrm{A}$ (Aldoa), triosephosphate isomerase 1 (Tpi1), glyceraldehyde-3-phosphate dehydrogenase (Gapdh), phosphoglycerate kinase 1 (Pgk1), phosphoglycerate mutase 1 (Pgam1), enolase 1 (Eno1), pyruvate kinase liver and red blood cell $(P k l r)$, pyruvate dehydrogenase kinase 1 (Pdk1), and Ldha. 18s RNA levels were used for normalization. ( $^{*} P \leq 0.01 \mathrm{Vhlh}^{-/-}$versus all groups; $\left.{ }^{\star \star \star}\right) P<0.001 \mathrm{Vhlh}^{-/-}$versus all groups (all Fisher LSD). ( $B$ ) Immunoblotting for HIF1 $\alpha$, PDK1, and LDHA of isolated islets of control, $\mathrm{Vhlh}^{-/-}, \mathrm{Hifl}^{-/-}$, and Vhlh ${ }^{-1-} \mathrm{Hif} 1 \alpha^{-/-}$mice $(n=2$ mice). (C) Lactate secretion of isolated islets of control $\left(n=7\right.$ mice), $\operatorname{Vhlh}^{-1-}(n=7$ mice), Hif1 $\alpha^{-/-}(n=3$ mice $)$, and Vhlh ${ }^{-/-} \mathrm{Hifl}^{-/-}(n=3$ mice) animals. $\left({ }^{\star}\right) P<0.05$ (Dunnett). $(D)$ Measurement of glycolytic flux in islets using radioactive $\mathrm{D}-\left[5-{ }^{3} \mathrm{H}\right] \mathrm{glu}-$ cose at $5 \mathrm{mM}$ and $20 \mathrm{mM}$ glucose of control $(n=8$ mice), Vhlh ${ }^{-1-}\left(n=7\right.$ mice), Hif1 $\alpha^{-/-}(n=5$ mice $)$, and Vhlh ${ }^{-1-} \mathrm{Hifl}^{-/-}(n=5$ mice $)$ animals. ( $\left.{ }^{*}\right) \quad P<0.05$ (Dunn). (E) Measurement of ATP levels in islets at 2 $\mathrm{mM}$ and $20 \mathrm{mM}$ glucose: Control ( $n=6$ of three mice), Vhlh $^{-/-}\left(n=6\right.$ of 3 mice), Hif $1 \alpha^{-/-}(\mathrm{n}=5$ of two mice), and Vhlh ${ }^{-1-} \mathrm{Hifl}^{-/-}\left(n=6\right.$ of two mice). $\left(^{\star}\right) P<0.05$ (Bonferroni).

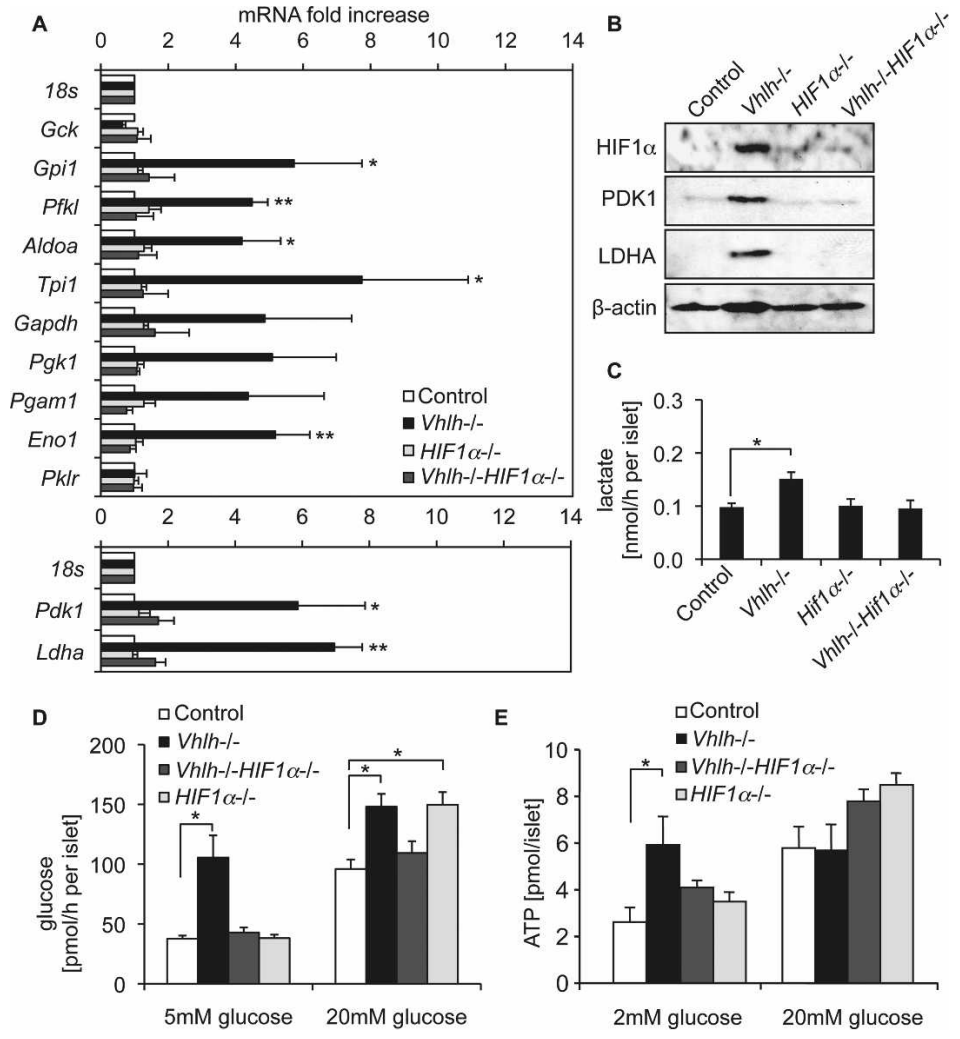




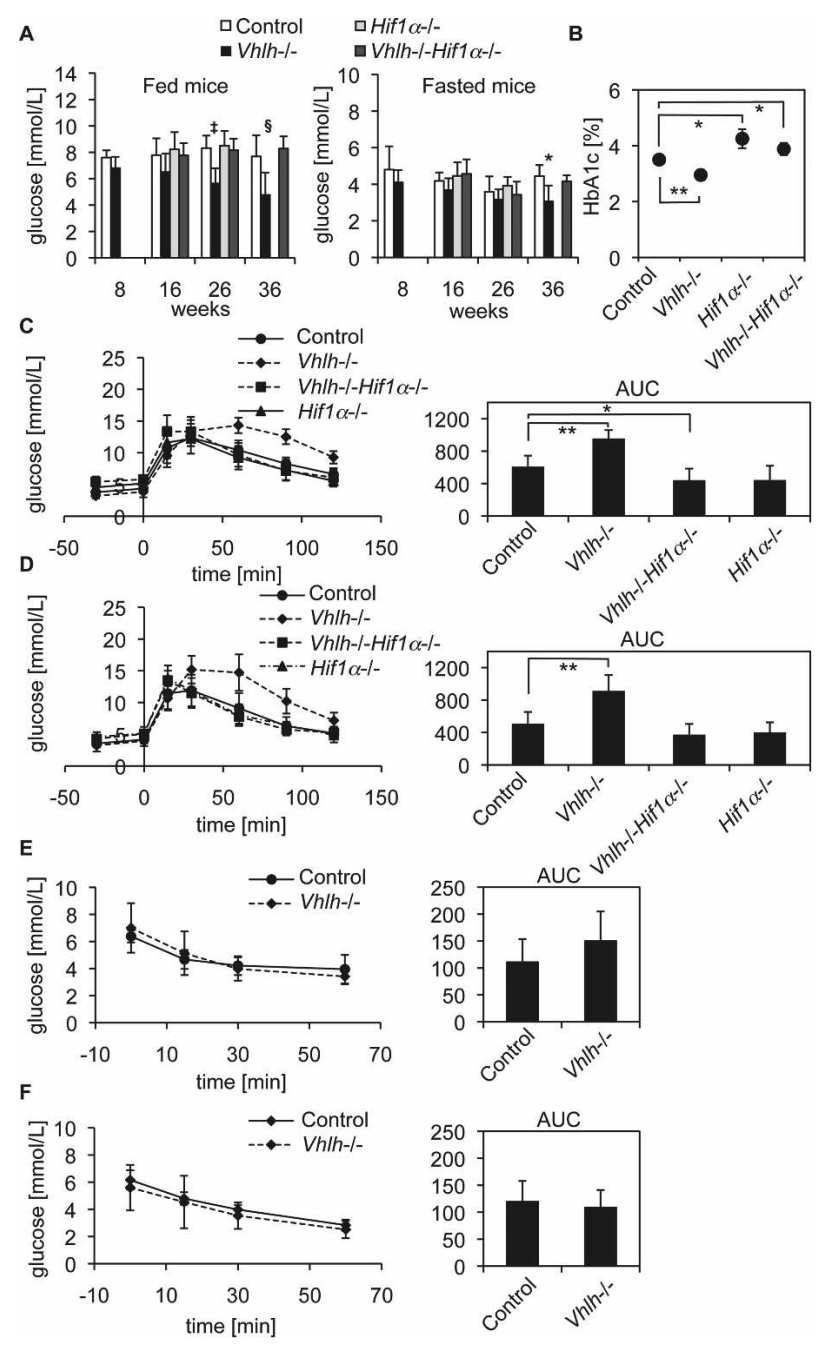

Figure 3. Glucose intolerance in $\beta$-cell-specific $\mathrm{Vhlh}^{-1-}$ mice. (A) Random-fed (left panel) and fasted (right panel) glucose levels in control, Vhlh ${ }^{-/-}$, Hif1 $1 \alpha^{-/-}$, and $\mathrm{Vhlh}^{-/-} \mathrm{Hifl}^{\mathrm{O}^{-/-}}$mice at 8 wk (only control and $\mathrm{Vhlh}^{-/-}$shown), 16 wk (all genotypes shown), 26 wk (all genotypes shown), and 36 wk (only control, $V h l h^{-1-}$, and Vhlh ${ }^{-1-} H$ if $1 \alpha^{-/-}$shown), ( $n \geq 5$ for all time points and genotypes). (‡) $P<0.001 \mathrm{Vhlh}^{-1-}$ versus all genotypes; (§) $P<0.01 \mathrm{Vhlh}^{-/-}$versus control and $\mathrm{Vhlh}^{-/-} \mathrm{Hifl}^{-\alpha^{--}} ;$( $\left.^{\star}\right) P<0.05$ Vhlh ${ }^{-/-}$versus control and Vhlh ${ }^{-1-} \mathrm{Hifl}^{-/-}$(all Fisher LSD). (B) HbAlc values for all genotypes at $26 \mathrm{wk}$ of age: Control $(n=6)$,

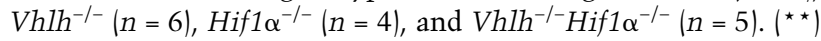
$P<0.001 ;\left(^{\star}\right) P<0.05$ (both Dunnett). (C) GTT and area under curve (AUC) of the GTT of male mice: Control $(n=12), \mathrm{Vhlh}^{-/-}$

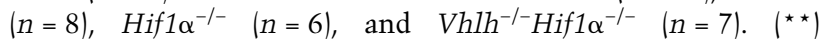
$P<0.001$; $\left(^{\star}\right) P<0.05$ (both Dunnett). $(D)$ GTT and AUC of GTT of female mice: Control $(n=12), \operatorname{Vhlh}^{-1-}(n=8), \operatorname{Hif1}^{-/-}(n=7)$, and $\mathrm{Vhlh}^{-1-} \mathrm{Hif1}^{-/-}(n=7) .\left(^{\star}\right) P<0.05$ (Dunnett). (E) ITT and AUC of ITT of male mice: Control $(n=11), \operatorname{Vhlh}^{-1-}(n=7) .(F)$ ITT and AUC of ITT of female mice: Control $(n=11)$, Vhlh ${ }^{-/-}$ $(n=8)$. Note that all data are presented as mean values \pm SD.

control mice at age of $26 \mathrm{wk}$. In the fasted state, basal glucose and insulin levels were similar in control and Vhlh-deficient mice (Figs. 3A [right panel], 4A [left bars]). Glucose increased plasma insulin concentrations by approximately twofold in control mice, but not in $\mathrm{Vhlh}^{-/-}$ mice 30 min after the glucose load (Fig. 4A, right bars). This finding is in agreement with the observation that $\mathrm{Vhlh}^{-/-}$mice display impaired glucose tolerance, and further implies that the glucose intolerance is a consequence of the failure of $\beta$ cells of $\mathrm{Vhlh}^{-/-}$mice to secrete adequate amounts of insulin in response to increased glucose load.

We next analyzed total insulin and glucagon content of the pancreas. While, as expected, glucagon content was unaffected by deletion of Vhlh in $\beta$ cells, insulin content was significantly reduced in the $\mathrm{Vhlh}^{-1-}$ mice
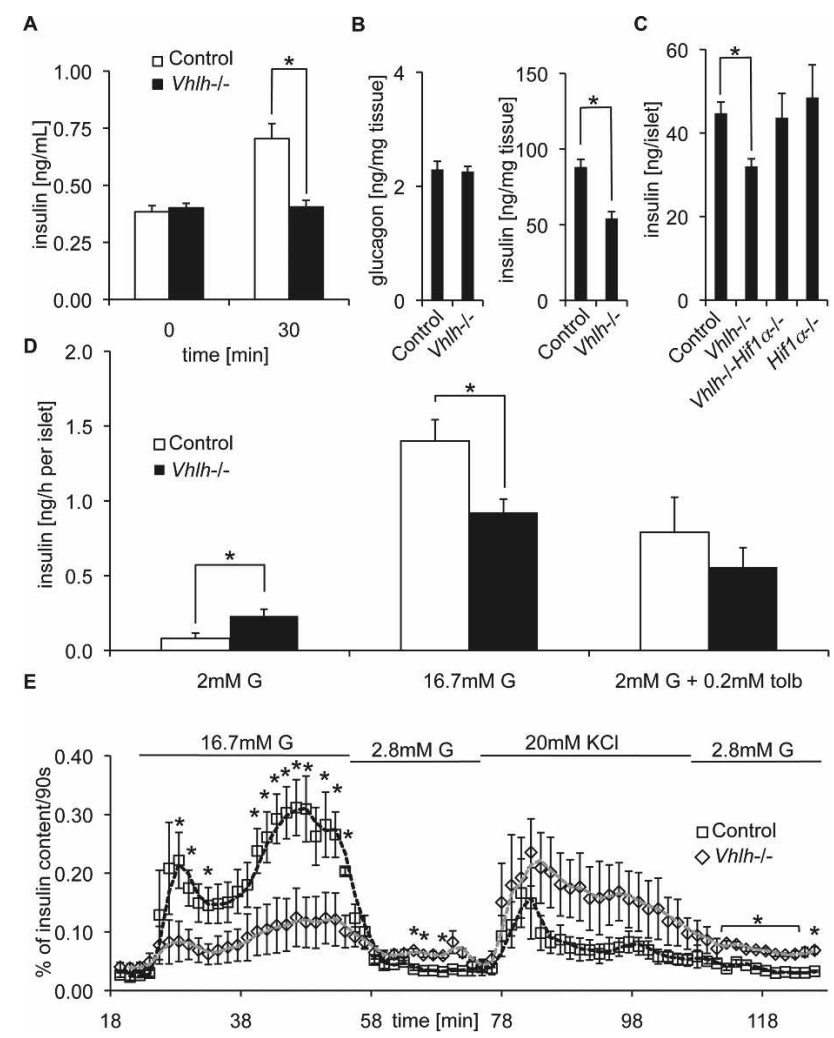

Figure 4. Abnormal insulin secretion in $\beta$-cell-specific $\mathrm{Vhlh}^{-/-}$ mice as well as in isolated islets. $(A)$ Glucose-induced insulin secretion in control versus Vhlh ${ }^{-1-}$ mice: Control $(n=19$ at 0 $\min ),(n=18$ at $30 \mathrm{~min}) ; V^{\prime} l h^{-1-}(n=12$ at $0 \mathrm{~min}),(n=14$ at 30 min). $\left(^{\star}\right) P<0.001$ (Mann-Whitney). (B) Total glucagon and insulin content per milligram of pancreas tissue: For glucagon: Control $(n=9), V h l h^{-1-}$ mice $(n=8)$; for insulin: Control $(n=13), V^{\prime} l h^{-/-}$mice $(n=12) .\left(^{\star}\right) P<1 \mathrm{E}^{-4}$ (Student). (C) Total insulin content of isolated islets: Control ( $n=6$ mice), $\mathrm{Vhlh}^{-/}$ ( $n=8$ mice), Hif1 $\alpha^{-1-}\left(n=6\right.$ mice), and Vhlh ${ }^{-1-}$ Hif $^{-1 \alpha^{--}}(n=7$ mice). $\left(^{\star}\right) P<0.01$ (Student). (D) Static incubation of 10 sizematched islets for $1 \mathrm{~h}$ at $2 \mathrm{mM}$ glucose (first panel, $n=7$ from four mice), stimulation with $16.7 \mathrm{mM}$ glucose (second panel, $n=6$ from four mice), and stimulation with $0.2 \mathrm{mM}$ tolbutamide (tolb) (third panel, $n=6$ from four mice). $\left(^{\star}\right) P<0.05$ (Mann-Whitney) (E) Islet perifusion of 30 control $(n=5$ mice) versus $30 \mathrm{Vhlh}^{-/-}(n=4 \mathrm{mice})$ islets. The perifusate was collected in 90-sec samples and normalized to insulin content. Dotted lines show moving average of control (black) and $\mathrm{Vhlh}^{-1-}$ (gray). Asterisks mark those time points where the difference between control and knockout islets reaches statistical significance $\left(^{\star}\right) P<0.05$ (Student or Mann-Whitney). 
when compared with control (Fig. 4B, left and right panels, respectively). To exclude that lower insulin amounts are a result of reduced islet mass, we determined, in addition, total insulin content of isolated size-matched islets. Islets derived from $\mathrm{Vhlh}^{-1-}$ mice had lower total insulin content when compared with control mice (Fig. $4 \mathrm{C})$.

Isolated $\mathrm{Vhlh}^{-1-}$ islets exhibited higher basal (at 2.8 $\mathrm{mM}$ glucose) insulin secretion than control islets (Fig. 4D, left bars). This suggests that constitutive basal hypersecretion of insulin contributes to the observed lower insulin content. Upon stimulation of these islets with $16.7 \mathrm{mM}$ glucose, insulin release was robustly induced in control islets, a response that was less prominent in $V_{\text {Vhlh }}{ }^{-1-}$ islets (Fig. 4D, middle bars). Treatment of control and $V h l h^{-1-}$ islets with tolbutamide, which binds to and closes the $\mathrm{K}_{\mathrm{ATP}}$ channel independently of changes in the ATP/ADP ratio, induced a notable insulin secretion response in both control and Vhlh ${ }^{-1-}$ islets (Fig. 4D, right bars). The observation that $\mathrm{Vhlh}^{-/-}$islets secrete similar levels of insulin as control islets when exposed to tolbutamide argues that Vhlh deficiency affects glucose-stimulated insulin secretion upstream of the $\mathrm{K}_{\mathrm{ATP}}$ channel.

Finally, to further confirm that the insulin secretion properties of $\mathrm{Vhlh}^{-/-} \beta$ cells are altered and to provide better insight into the kinetics of insulin secretion, we performed perifusion assays on isolated islets. $\mathrm{Vhlh}^{-/-}$ islets perifused with $16.7 \mathrm{mM}$ glucose secreted significantly lower amounts of insulin than control islets. During stimulation, first and second phase of insulin secretion were blunted, whereas basal insulin secretion was slightly increased (Fig. 4E). Subsequent incubation with high- $\mathrm{K}^{+}(20 \mathrm{mM})$ to induce membrane depolarization and insulin secretion evoked a similar secretory response in control and $\mathrm{Vhlh}^{-/-}$islets (Fig. 4E). This data suggest that Vhlh deficiency negatively affects both first- and second-phase insulin secretion in response to a glucose stimulus.

\section{Changes in $\left.\mathrm{Ca}^{2+}\right]_{i}$ in Vhlh-deficient $\beta$ cells are rescued by combined Hif1 $\alpha$ deletion}

We correlated the changes in insulin secretion and islet ATP content to changes in cytosolic $\mathrm{Ca}^{2+}$ concentration $\left(\left[\mathrm{Ca}^{2+}\right]_{\mathrm{i}}\right)$ measured by fura-2 whole-islet microfluorimetry. In control islets (Fig. 5A), $16.7 \mathrm{mM}$ glucose elevated $\left[\mathrm{Ca}^{2+}\right]_{i}$ to a sustained plateau. Addition of tolbutamide (applied immediately after high glucose) had only a marginal additional effect. Effects of both glucose and tolbutamide were reversed upon their withdrawal from the perifusion medium. Consistent with our data showing elevated basal secretion of insulin upon Vhlh deletion, islets from $\mathrm{Vhlh}^{-/-}$mice displayed elevated basal $\left[\mathrm{Ca}^{2+}\right]_{\mathrm{i}}$ when compared with that of control (Fig. 5B). When stimulated by $16.7 \mathrm{mM}$ glucose, a transient rise in $\left[\mathrm{Ca}^{2+}\right]_{\mathrm{i}}$ was observed, but the response was significantly delayed $(271 \pm 48$ vs. $99 \pm 8 \mathrm{sec}$ in controls). In addition, rather than showing a sustained increase, oscillations started from a plateau only slightly above basal in response to

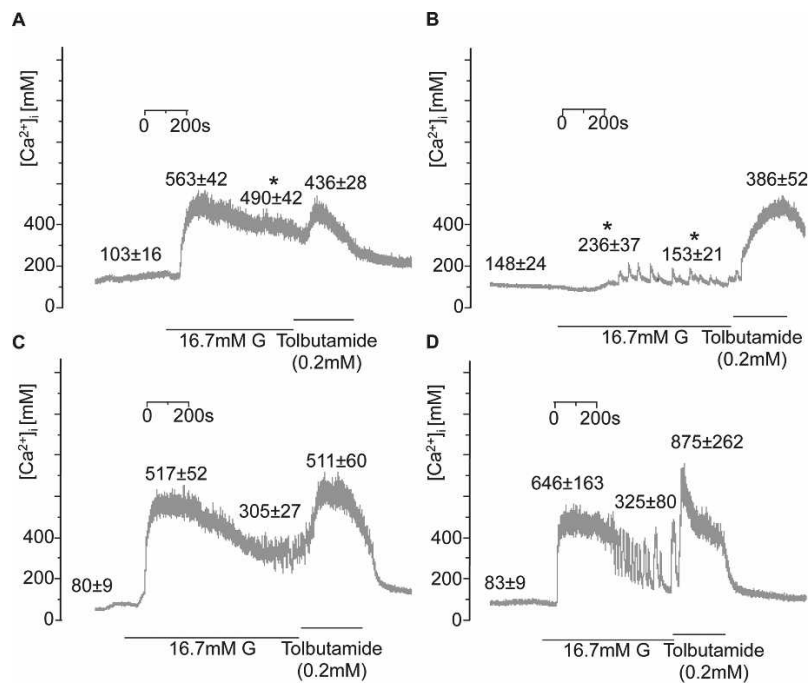

Figure 5. Reduced $\left[\mathrm{Ca}^{2+}\right]_{\mathrm{i}}$ responses in Vhlh-deficient islets. Glucose- and tolbutamide- $\left[\mathrm{Ca}^{2+}\right]_{\mathrm{i}}$ responses in control $(A)$, Vhlh $^{-/-}(B)$, Hif1 $\alpha^{-/-}(C)$, and Vhlh ${ }^{-1-} \mathrm{Hifl}^{-/-}(D)$ animals. Representative traces are shown for each group. Means \pm SE are shown for basal and peak responses to glucose, followed by plateau average and peak response to tolbutamide. $(A)\left[\mathrm{Ca}^{2+}\right]_{\mathrm{i}}$ response of control $\beta$ cells $\left(n=12\right.$ islets from three mice). $\left({ }^{\star}\right)$ $P<0.05$ versus $\mathrm{Hifl}^{-/-}$(Fisher LSD). (B) $\left[\mathrm{Ca}^{2+}\right]_{\mathrm{i}}$ response of Vhlh ${ }^{-1-} \beta$ cells $\left(n=7\right.$ islets from two mice). $\left({ }^{\star}\right) P<0.05$ versus control and $\mathrm{Hif1} \alpha^{-/-}$(Fisher LSD). (C) $\left[\mathrm{Ca}^{2+}\right]_{\mathrm{i}}$ response of $H i f 1 \alpha^{-/-} \beta$ cells $\left(n=8\right.$ islets from two mice). (D) $\left[\mathrm{Ca}^{2+}\right]_{\mathrm{i}}$ response of $V h l h^{-1-} H i f 1 \alpha^{-1-} \beta$ cells ( $n=4$ islets from one mouse). In $A-D$, the values given above the traces are mean values \pm SE (in nanomolar) measured before addition of glucose, during the initial peak in the presence of glucose, in the presence of glucose at steady-state, and during the peak evoked by addition of tolbutamide.

stimulation with $16.7 \mathrm{mM}$ glucose. However, the response to tolbutamide was intact, and in the presence of the $\mathrm{K}_{\mathrm{ATP}}$-channel blocker, $\left[\mathrm{Ca}^{2+}\right]_{\mathrm{i}}$ rose to values as high as in control islets. The effects of Vhlh deletion were prevented by also ablating Hif1 $\alpha$ (Fig. 5D). In the latter mice, $\left[\mathrm{Ca}^{2+}\right]_{\mathrm{i}}$ promptly increased to a plateau, and although oscillations were seen, these started from a high plateau and were separated by only brief intervals. Ablating Hif1 $\alpha$ alone (Fig. 5C) had no detectable effects on $\left[\mathrm{Ca}^{2+}\right]_{\mathrm{i}}$ handling, and responses were similar to those seen in control and Vhlh ${ }^{-1-} \mathrm{Hifl}^{-/-}$islets. Whole-cell patch-clamp recordings revealed no statistically significant differences in the peak $\mathrm{Ca}^{2+}$-current amplitudes between the control and the various knockout mice (Supplemental Fig. S3).

\section{Impaired glucose-evoked electrical activity in Vhlh-deficient $\beta$ cells}

Electrical activity was measured from $\beta$ cells in intact islets using the whole-islet patch-clamp approach (Gopel et al. 1999). In control islets (Fig. 6A), the $\beta$-cell resting potential measured at $2 \mathrm{mM}$ glucose was $-76 \pm 4 \mathrm{mV}$. Addition of $16.7 \mathrm{mM}$ glucose resulted in membrane de- 
A

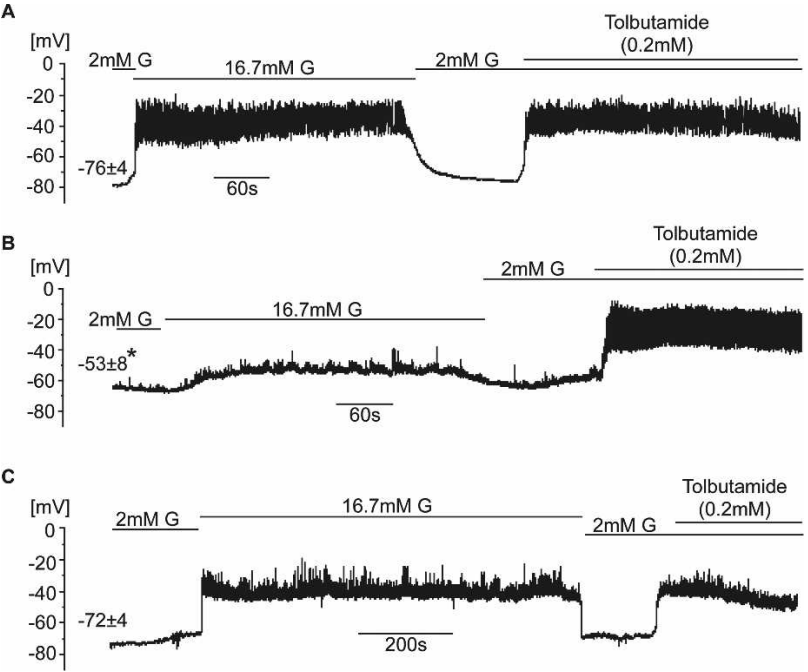

Figure 6. Effects of Vhlh silencing on $\beta$-cell electrical activity. $(A-C)$ Representative membrane potential recordings from $\beta$ cells in control islets $(A)\left(n=5\right.$ cells from two mice), $V h l h^{-/-}$

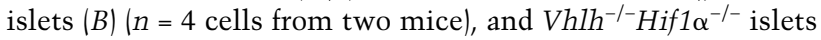
(C) ( $n=3$ cells from two mice) at $2 \mathrm{mM}$ glucose, $16.7 \mathrm{mM}$ glucose, and $2 \mathrm{mM}$ glucose $+0.2 \mathrm{mM}$ tolbutamide as indicated by horizontal lines. Values given above the traces at $2 \mathrm{mM}$ glucose are resting membrane potential (mean values $\pm \mathrm{SE}$ ). $\left({ }^{\star}\right) P=0.028$ (Dunnett).

polarization and uninterrupted action potential firing, effects that were reversed upon withdrawal of high glucose. Subsequent addition of $0.2 \mathrm{mM}$ tolbutamide promptly and reversibly depolarized the $\beta$ cell and evoked action potential firing. In $\mathrm{Vhlh}^{-1-} \beta$ cells (Fig. $6 \mathrm{~B}$ ), the resting membrane potential was $-53 \pm 8 \mathrm{mV}$. The response to glucose was significantly reduced: A much smaller depolarization was obtained and only occasional bursts of action potential were seen. However, compared with controls (Fig. 6A,B), the response to tolbutamide remained intact and was similar to that seen in control islets. In Vhlh ${ }^{-/-} H i f 1 \alpha^{-1-} \beta$ cells (Fig. 6C) and in Hif1 $\alpha^{-/-} \beta$ cells (data not shown), the resting potential at $2 \mathrm{mM}$ glucose averaged at $-72 \pm 4 \mathrm{mV}$ and $-69 \pm 3 \mathrm{mV}$ (data not shown), respectively. The response to glucose was restored and they also exhibited the normal effects of tolbutamide.

\section{Discussion}

Here we report a key function of the pVHL-HIF pathway in the control of $\beta$-cell metabolism, insulin secretion, and whole-body glucose homeostasis. Specifically, we show that $\beta$-cell-specific deletion of Vhlh in mice leads to induction of genes whose products promote glucose uptake (Slc2a1), glycolysis (Gpi1, Pfkl, Aldoa, Tpi1, Gapdh, Pgk1, Pgam1, and Eno1), and decrease pyruvate metabolism in mitochondria (Pdk1 and Ldha). These effects result in an enhanced glycolytic rate, the reprogramming of the intracellular fate of glucose toward lactate, and the efficient production of glycolytically derived ATP even at low glucose concentrations. Combined deletion of
Vhlh and Hif1 $\alpha$ prevented these effects, implying that the shift in cellular fuel utilization from mitochondrial respiration to glycolysis and the ensuing increase in ATP levels in $\mathrm{Vhlh}^{-/-} \beta$ cells is mediated by HIFl $\alpha$. We further show that Vhlh-deficient $\beta$ cells display increased basal insulin secretion and that islet (principally reflecting the $\beta$ cells) ATP content at $2 \mathrm{mM}$ glucose in $\mathrm{Vhlh}^{-/}$ islets is 2.5 -fold higher than in control islets and in fact, as high as in control islets exposed to $20 \mathrm{mM}$ glucose (Figs. 2E, 4D). Vhlh ${ }^{-/-} \beta$ cells showed elevated resting membrane potential and $\mathrm{Ca}^{2+}$ levels under these conditions (Figs. 5B, 6B). Collectively, these data suggest that glycolytically derived ATP contributes to the glucoseevoked stimulation of $\beta$-cell electrical activity and insulin secretion. However, the findings that glucose-stimulated electrical activity, changes of $\left[\mathrm{Ca}^{2+}\right]_{\mathrm{i}}($ Figs. $5 \mathrm{~B}, 6 \mathrm{~B})$, and insulin secretion (Fig. 4D) were markedly impaired in $\mathrm{Vhlh}^{-1-}$ islets indicates that up-regulation of glycolysis alone is not sufficient to evoke the full secretory response. As discussed later, these findings suggest that other mitochondrial signals that result from glucose metabolism through mitochondrial oxidative phosphorylation are also necessary.

Glucose is the primary physiological secretagogue for pancreatic $\beta$ cells. It enters the $\beta$ cells via glucose transporters type 2 (SLC2A2; also referred to as GLUT2) and is then further metabolized to pyruvate, which is used to produce ATP primarily through mitochondrial oxidative phosphorylation (Levitsky et al. 1994). We show that $V h l h$-deficient $\beta$ cells express high levels of the glucose transporter SLC2A1 in a HIF1 $\alpha$-dependent manner. Unlike SLC2A2 (GLUT2), which has a high $\mathrm{K}_{\mathrm{m}}$ for glucose ( $\sim 25 \mathrm{mM})$, SLC2A1 (GLUT1) has a low $\mathrm{K}_{\mathrm{m}}(\sim 6 \mathrm{mM})$, and thus is able to support glucose uptake even under low glucose conditions (Levitsky et al. 1994; Noel and Newgard 1997). SLC2A1 is expressed in most cell types (an exception being normal $\beta$ cells) and represents an established HIF-target gene product. It is up-regulated in many cancer cells to facilitate glucose uptake to meet the increased energy demand associated with high rates of growth and proliferation (Shaw 2006). Thus, HIF1 $\alpha$ mediated up-regulation of SLC2A1 and of other glycolytic genes in $\mathrm{Vhlh}^{-/-} \beta$ cells likely contributes to the efficient uptake and metabolic processing of glucose also in the fasted state. This interpretation is consistent with our data indicating that islets from $\mathrm{Vhlh}^{-1-} \beta$ cells are characterized by increased glycolytic rate that is dependent on HIF $1 \alpha$ (Fig. 2D).

The HIF $1 \alpha$ transcriptional targets that are induced in $\mathrm{Vhlh}^{-1-} \beta$ cells also include PDK1 and LDHA. PDK1 inactivates the TCA cycle enzyme pyruvate dehydrogenase (PDH), which generates acetyl-CoA from pyruvate. By suppressing PDH, PDK1 limits the influx of pyruvate into the TCA cycle and thus diverts pyruvate away from mitochondrial oxidative phosphorylation (Papandreou et al. 2006). LDHA, on the other hand, catalyzes the conversion of pyruvate to lactate. The induction of LDHA would facilitate an efficient recycling of the glycolytic cofactor $\mathrm{NAD}^{+}$, which is required to maintain glycolytic ATP production (Fantin et al. 2006). The end product of 
these enzymatic activities is a reduction in mitochondrial respiration and production of glycolytically derived ATP and lactate. That $V h l h^{-1-} \beta$ cells have undergone such a shift in glucose metabolism is supported by the presence of enhanced lactate secretion from $\mathrm{Vhlh}^{-/-}$islets as well as the constitutive production of ATP at low glucose. That mitochondrial activity is critical for normal insulin secretion is further supported by previous work demonstrating that depletion of mitochondrial DNA inhibits glucose-stimulated insulin secretion and that manipulating the activities of LDHA or PDH in $\beta$ cell lines or isolated rat islets likewise affects pyruvate metabolism with consequent effects on insulin secretion (Kennedy et al. 1998; Tsuruzoe et al. 1998; Ishihara et al. 1999; Ainscow et al. 2000; Nicholls et al. 2002).

$\beta$ cells express both $\mathrm{PDH}$ and pyruvate carboxylase (PC) so that pyruvate derived from glucose metabolism enters in a fed state into mitochondrial metabolic pathways in roughly equal proportions through the oxidative (via PDH) and the anaplerotic (via PC) entry points (Khan et al. 1996; Schuit et al. 1997; Lu et al. 2002). The latter generates, through a process termed "pyruvate cycling," excess of some, but not all TCA cycle intermediates that exit the mitochondria to engage in various cytosolic pathways that lead back to pyruvate and produce other important amplifying signals that contribute to glucose-stimulated insulin secretion (MacDonald et al. 2005). Therefore, one could imagine that in $V h l h^{-/-}$islets, anaplerotic entry of pyruvate into mitochondria generates certain signals that contribute to increased insulin secretion in response to a glucose stimulus and thus help to explain why $\mathrm{Vhlh}^{-1-}$ islets displayed some glucose-stimulated insulin secretion. In this regard, the activity of the anaplerotic pathway depends on acetyl-CoA, a positive allosteric modulator of PC. As fatty acids represent a major endogenous energy source for islets (Yaney and Corkey 2003), we propose that fatty acid oxidation is a likely source for acetyl-CoA production in $\mathrm{Vhlh}^{-/-}$islets. The prediction that HIF1 $\alpha$-mediated PDK1 and LDHA up-regulation plays a role in attenuating full mitochondrial activity and thus the efficient generation of key mitochondrial signals is consistent with our observation that glucose-stimulated secretion is less efficient in $V h l h^{-1-}$ islets than in control islets (Fig. 4D). Several mitochondrial signals are discussed to play an important role in the regulation of insulin secretion (Maechler and Wollheim 2001; Ivarsson et al. 2005). For example, recently it was reported that mitochondrial GTP, which is produced proportionally to TCA cycle flux, represents an important signal for insulin secretion (Kibbey et al. 2007). The identity of the mitochondrial signal(s) lacking in $V_{h l h}{ }^{-1} \beta$ cells remains to be determined. However, our data illustrates the crucial importance of the pVHL-HIF1 $\alpha$ axis for precise cellular fuel utilization and the maintenance of whole-body glucose homeostasis.

Type 2 diabetes is a progressive disease: Main underlying reasons include a continuous age-dependent decline in $\beta$-cell function and $\beta$-cell mass. Factors that are thought to contribute to progressive loss of $\beta$-cell function/mass include increased amounts of nonesterified fatty acids, hormones, and proinflammatory cytokines that are released from the adipose tissue in obese individuals and are involved in the development of insulin resistance (Kahn et al. 2006). Initially, the adaptive response of $\beta$ cells to insulin resistance involves both changes in mass and function that act to maintain normal glucose tolerance. In prediabetic ZDF rats, $\beta$-cell mass expansion is associated with the activation of certain hypoxia-inducible target genes (Li et al. 2006). We also found that in $o b / o b$ mice, which develop islet hyperplasia as a result of an adaptive response to spontaneous obesity due to leptin deficiency, certain HIF-target genes including S1c2a1, Pdk1, and Hif1 $\alpha$ itself are activated (J. Zehetner and W. Krek, unpubl.). Thus, HIF target gene activation may be an early event, occurring as part of an adaptive response accompanying $\beta$-cell mass expansion, taking place prior to overt diabetes, at least in rodent models. Importantly, many other signals including growth factors, hormones, and inflammatory cytokines such as TNF $\alpha$ are potent activators of HIF under normoxia (Cramer et al. 2003; Hellwig-Burgel et al. 2005). For example, TNF $\alpha$ is released by macrophages that populate the adipose tissue in obese states (Coppack 2001). $\mathrm{TNF} \alpha$ is known to activate the transcription factor NF$\kappa \mathrm{B}$, which has been shown recently to induce HIF1 $\alpha$ transcription (Rius et al. 2008). Thus, it is conceivable that in addition to low oxygen, levels of one or more other, as yet unidentified signals controlling HIF-target gene expression during $\beta$-cell mass expansion are likewise increased.

Based on the above considerations and our present experimental results, it is tempting to speculate that chronic glycolytic energy production due to increased HIF $1 \alpha$ activity, combined with an absence of mitochondrial metabolites, exacerbate the slip of $\beta$ cells into the decompensation phase and ultimately leads to $\beta$-cell failure that is a hallmark in the pathogenesis of type 2 diabetes. According to this model, down-regulation of HIF1 $\beta /$ ARNT and certain HIF-target genes, as has been reported to occur in type 2 diabetes (Gunton et al. 2005) would occur, at least in some individuals, during the later stages of the disease. Further analysis of the HIF system, especially in prediabetic individuals, is therefore warranted. The finding that activation of the HIF system is linked to abnormal insulin secretion properties of $\beta$ cells finally raises the interesting possibility that it represents a potential molecular target for therapeutic intervention in type 2 diabetes.

\section{Materials and methods}

\section{Animal models}

The Rip2-Cre and Vhlh ${ }^{\mathrm{fl} / \mathrm{fl}}$ and $H i f 1 \alpha^{\mathrm{fl} / \mathrm{fl}}$ mice have been described (Herrera 2000; Haase et al. 2001; Schipani et al. 2001). The mice were mated to obtain conditional $\mathrm{Vhlh}^{-/-}$, Hif $1 \alpha^{-/-}$, and Vhlh ${ }^{-/-} \mathrm{Hif} 1 \mathrm{\alpha}^{-/-}$mice with the same mixed background. All experiments were performed using littermates as controls. These control groups were mice lacking Cre-recombinase, as well as mice being heterozygous for Vhlh, Hif1 $\alpha$, or both. PCRmediated genotyping as well as detection of $\beta$-cell-specific Cremediated recombination at the Vhlh and Hif1 $\alpha$ loci were per- 
formed as described in the Supplemental Material as well as Haase et al. (2001) and Schipani et al. (2001). Plasma glucose levels were monitored at the beginning of the night phase for the random-fed group and the consecutive morning after a 12-h food deprivation for the fasted group. HbAlc levels were determined using a commercially available analysis kit (DCA 2000; Bayer Diagnostics). All animal experiments were approved by the Veterinary Office of Zurich (Switzerland).

\section{Islet isolation and islet cell preparation}

The mice were sacrificed by cervical dislocation. The pancreas was removed, placed in precooled HBSS solution (Sigma-Aldrich) containing $40 \mathrm{mM}$ Hepes ( $\mathrm{pH} 7.5)$, and cut into small pieces to remove fatty parts. The remaining organ pieces were resuspended in collagenase solution (HBSS, $40 \mathrm{mM}$ Hepes at $\mathrm{pH} 7.5$, $10 \mathrm{mM} \mathrm{CaCl}_{2}, 4 \mathrm{mg}$ Collagenase $\mathrm{P}$ [Roche]) and shaken at $37^{\circ} \mathrm{C}$ using a Wrist-Action Shaker (Burrel Scientific). The digestion was stopped (HBSS, $40 \mathrm{mM}$ Hepes at $\mathrm{pH} 7.5,10 \%$ FCS), washed, and filtered through a tea strainer. The islets were separated applying a density gradient created by resuspending the pellet in Histopaque-1077 (Sigma-Aldrich) and layering HBSS containing $10 \%$ FCS. The supernatant containing the islets was washed and the islets were handpicked under a microscope. Isolated islets were cultured in RPMI 1640 (10\% FCS, 1\% penicillin/ streptomycin, $11.1 \mathrm{mM}$ D-glucose) at $37^{\circ} \mathrm{C}$ and $5 \% \mathrm{CO}_{2}$.

\section{Immunohistochemistry (IHC) and IF}

IHC and IF staining were performed as previously described (Thoma et al. 2007). In brief, IHC antigen retrieval was performed with citrate buffer $\left(\mathrm{pH}\right.$ 6.0) for $10 \mathrm{~min}$ at $98^{\circ} \mathrm{C}$. Endogenous peroxidase was quenched by $3 \%$ hydrogen peroxide/ $10 \%$ methanol. Nonspecific sites were blocked with $10 \%$ normal horse serum with $0.3 \%$ Triton X-100 in combination with the Avidin-Biotin kit (Vector Laboratories). After incubation with secondary antibodies, signal amplification and detection was performed using $\mathrm{ABC}$ signal amplification and $\mathrm{DAB}$ staining (all Vector Laboratories). The following primary antibodies were used: anti-pVHL $(\mathrm{m})_{\mathrm{CT}}$ antibody (Hergovich et al. 2003), antiARNT (Santa Cruz Biotechnologies, sc-8076), anti-SLC2A1 (Abcam, ab14683), anti-insulin (Linco, \#4011-01), anti-glucagon (Zymed, \#18-0064 or Novus Biologicals \#600-1506). HIF1 $\alpha$ (Novus Biologicals, \#100-105) staining was performed using the DakoCytomation Catalyzed Signal Amplification System. IF confocal images were acquired with a confocal microscope DMIRS2 (Leica) by sequentially scanning. IHC images were acquired with an Axioplan 2 microscope (Zeiss).

\section{Immunoblot analysis}

One-hundred-fifty mouse islets were lysed in SDS-PAGE sample buffer (40 mM Tris/Cl at pH 6.8, 1\% SDS, $50 \mathrm{mM} \beta$-ME, $6 \%$ Glycerol). The lysates were run on $7.5 \%-12.5 \%$ gradient polyacrylamide gels, transferred to nitrocellulose membranes, and visualized by immunoblotting. The following primary antibodies were used: anti-pVHL $(\mathrm{m})_{\mathrm{CT}}$ antibody (Hergovich et al. 2003), anti-SLC2A1 (Abcam, ab14683), anti-HIF1 $\alpha$ (Novus Biologicals, \#100-105), anti-tubulin (Santa Cruz Biotechnologies, sc-9935), anti-PDK1 (Stressgen, KAP-PK112), anti-LDHA (Santa Cruz Biotechnologies, sc-27230), and anti- $\beta$-actin (Sigma-Aldrich, \#A5441).

\section{Real-time PCR}

For isolation of $\mathrm{Vhlh}^{-1-}$, Hif1 $\alpha^{-/-}$, and $\mathrm{Vhlh}^{-/-} \mathrm{Hif1 \alpha ^{-/- }}$ islets, mice at an age between 20 and 30 wk were used. Freshly isolated islets were handpicked and total RNA was isolated using MicroRNA kit (Stratagene). Total pancreas was used directly for RNA extraction after excision. Reverse transcriptase reactions were performed with Ready-To-Go You-Prime First-Strand beads (Amersham Biosciences) prior to real-time PCR analysis on a Lightcycler 480 (Roche) with SybrGreen I Master mix (Roche). All experiments were performed using three mice per genotype. Fold changes were normalized to $18 S$ RNA levels. For primer sequences, see the Supplemental Material.

\section{Microarray experiment}

Three wild-type mice between 18 and 26 wk were compared with three $\mathrm{Vhlh}^{-/-}$littermates. Detailed experimental description is placed in the Supplemental Material. Array analysis was performed using Genespring software (Agilent). The expression data discussed in this publication can be viewed under the GEO series accession number GSE11484 on NCBI Gene Expression Omnibus (http://www.ncbi.nlm.nih.gov/geo).

\section{Lactate measurements}

A total of 20 islets of each genotype were picked and preincubated $1 \mathrm{~h}$ at $2.5 \mathrm{mM}$ Glucose in Krebs-Ringer Bicarbonate Hepes (KRBH) buffer (124 mM NaCl, $5.6 \mathrm{mM} \mathrm{KCl}, 2.5 \mathrm{mM} \mathrm{CaCl}_{2}, 20$ $\mathrm{mM}$ Hepes at $\mathrm{pH}$ 7.4) followed by an incubation of $1 \mathrm{~h}$ at 16.7 $\mathrm{mM}$ Glucose in KRBH buffer. Lactate levels in the supernatant were determined using the lactate assay kit (BioVision).

\section{Glucose utilization}

Glucose utilization in islets was determined by measuring the conversion of D- $\left[5-{ }^{3} \mathrm{H}\right]$-glucose (Hartmann Analytic) to $\left[{ }^{3} \mathrm{H}\right] \mathrm{H}_{2} \mathrm{O}$ using a water diffusion procedure as described (Ashcroft et al. 1972). Batches of 15 islets were incubated in medium containing $\mathrm{D}-\left[5-{ }^{3} \mathrm{H}\right]$-glucose at the given concentrations in rubberclosed scintillation tubes containing $\mathrm{H}_{2} \mathrm{O}$. After an incubation of $2 \mathrm{~h}$, the reaction was stopped with $0.2 \mathrm{~N} \mathrm{HCl}$ and left for equilibration for $24 \mathrm{~h}$ at $37^{\circ} \mathrm{C}$. Thereafter, radioactivity of formed $\left[{ }^{3} \mathrm{H}\right] \mathrm{H}_{2} \mathrm{O}$ was measured.

\section{ATP measurements}

Batches of 10 islets were incubated for $2 \mathrm{~h}$ at $37^{\circ} \mathrm{C}$ in $\mathrm{KRBH}$ solution containing $2 \mathrm{mg} / \mathrm{mL}$ BSA and various concentrations of glucose. After this time, ice-cold $10 \%$ perchloric acid was added and islets were disrupted by vortexing for $10 \mathrm{sec}$. Each glucose concentration was tested in five to six separate assays, and ATP was measured using an ATP bioluminescence assay kit CLS II (Roche) and a TD20/20 luminometer (Turner Designs).

\section{GTT and insulin tolerance test (ITT)}

Female and male mice, 16-20 wk of age, were fasted overnight. Glucose levels were determined $30 \mathrm{~min}$ before glucose injection. After an i.p. injection of $1.5 \mathrm{~g}$ of glucose $/ \mathrm{kg}$ bodyweight, glucose levels were determined with an OneTouch Ultra glucometer (Lifescan) at $0,15,30,60,90$, and 120 min using blood from the tail vain. For the ITT, 20- to 24-wk-old random-fed female and male mice were used. After an i.p. injection of 0.75 $\mathrm{U}$ of insulin/kg bodyweight (Humulin R; Eli Lilly), glucose levels were determined at $0,15,30$, and $60 \mathrm{~min}$ as described above. To exclude any heterodimeric influence on glucose or insulin tolerance, Vhlh ${ }^{\mathrm{wt} /-}$; Hif1 $\alpha^{\mathrm{wt} /-}$; and Vhlh ${ }^{\mathrm{wt} /-} \mathrm{Hif} 1 \alpha^{\mathrm{wt} /-}$ were initially tested (for ITT only Vhlh ${ }^{\mathrm{wt} /-}$ ). Female and male mice were 
analyzed separately and areas under curve (AUC) were calculated.

\section{Glucose-induced insulin secretion in vivo}

Female and male mice, 26 wk of age, were fasted overnight. To obtain sufficient blood serum for each time point, the tested animal was euthanized. Insulin levels were measured with a radioactive insulin assay (Insulin-CT, Schering) either at the beginning of the experiment or $30 \mathrm{~min}$ after an i.p. injection of $1.5 \mathrm{~g}$ of glucose per kilogram of bodyweight.

\section{Total insulin and glucagon content of pancreas}

Pancreatic glands from 26-wk-old mice were excised, weighed, and sonicated three times for $10 \mathrm{sec}$ at $25 \%$ of maximal energy with a Bandolin Sonoplus HD2200 in acid ethanol $2 \%$ concentrated $\mathrm{HCl}$ in EtOH). Samples were incubated $20-24 \mathrm{~h}$ at $-20^{\circ} \mathrm{C}$ and vortexed for $20 \mathrm{sec}$ before pelleting the tissue. Serial dilutions were prepared with PBS and measured using an insulin ELISA (Mercodia). Glucagon content was measured from the same aliquots as for total insulin content using a glucagon radioimmunosassay (Linco).

\section{Total insulin content of isolated islets}

Insulin content was determined from 20 islets after preincubation for $1 \mathrm{~h}$ at $2.5 \mathrm{mM}$ glucose. Islets were transferred into acid ethanol and incubated $20-24 \mathrm{~h}$ at $-20^{\circ} \mathrm{C}$. Serial dilutions were prepared with PBS and insulin content determined by ELISA (Mercodia). Values were normalized for area using the imaging software Metamorph (Molecular Devices). Normalization to islet DNA by picogreen gave similar values (data not shown).

\section{Static incubation of islets}

Isolated islets were preincubated at $2 \mathrm{mM}$ glucose for $1 \mathrm{~h}$. Groups of 10 size-matched islets of control and $\mathrm{Vhlh}^{-1-}$ mice were incubated for $1 \mathrm{~h}$ in $2 \mathrm{mM}$ glucose, $16.7 \mathrm{mM}$ glucose, or 2 $\mathrm{mM}$ glucose plus $0.2 \mathrm{mM}$ tolbutamide (tolb). The insulin concentrations of all supernatants were determined using an ELISA (Mercodia).

\section{Islet perifusion}

Insulin secretion by perifused islets isolated from $\mathrm{Vhlh}^{-/-}$mice was compared with control mice. Thirty size-matched islets of each genotype were preincubated for $2 \mathrm{~h}$ in RPMI 1640 supplemented with $2.8 \mathrm{mM}$ glucose in the corresponding perifusion columns. Flux was $500 \mu \mathrm{L} / \mathrm{min}$. After autosampling (every 90 $\mathrm{sec}$ ), the insulin concentrations (undiluted samples) were determined using an ELISA (Mercodia). Stimulation was performed with $16.7 \mathrm{mM}$ glucose as well as $20 \mathrm{mM} \mathrm{KCl}$ in $\mathrm{KRBH}$ buffer $\left(124 \mathrm{mM} \mathrm{NaCl}, 5.6 \mathrm{mM} \mathrm{KCl}, 2.5 \mathrm{mM} \mathrm{CaCl}_{2}, 20 \mathrm{mM}\right.$ Hepes at $\mathrm{pH}$ 7.4). Values were normalized to total insulin content (TIC), determined as described above.

\section{Electrophysiology}

$\mathrm{Ca}^{2+}$ currents were recorded on dispersed $\beta$ cells in the wholecell configuration. Signals were amplified and analyzed using EPC-9 patch-clamp amplifiers and the software Pulse+Pulsefit (Heka Electronic). Cells were maintained at $32^{\circ} \mathrm{C}$ and perifused with a solution containing $118 \mathrm{mM} \mathrm{NaCl}, 20 \mathrm{mM}$ TEA-Cl $2,5.6$
$\mathrm{mM} \mathrm{KCl}, 2.6 \mathrm{mM} \mathrm{CaCl}_{2}, 1.2 \mathrm{mM} \mathrm{MgCl}, 5 \mathrm{mM}$ HEPES, and 5 $\mathrm{mM}$ glucose $(\mathrm{pH} 7.4)$ at $32^{\circ} \mathrm{C}$ with $\mathrm{NaOH}$. The pipette solution contained $125 \mathrm{mM}$ L-Glutamate, $10 \mathrm{mM} \mathrm{CsCl}, 10 \mathrm{mM} \mathrm{NaCl}, 1$ $\mathrm{mM} \mathrm{MgCl}$, $5 \mathrm{mM}$ Hepes, $50 \mathrm{mM}$ EGTA, $3 \mathrm{mM} \mathrm{Mg-ATP}$, and $0.1 \mathrm{mM}$ cAMP. The $\mathrm{pH}$ was adjusted to 7.35 at $32^{\circ} \mathrm{C}$. Electrodes were pulled from borosilicate pipettes, coated with Sylgard, and heat polished. Filled with the described pipette solution, they had resistances between 4 and $7 \mathrm{M} \Omega$. Access resistance was $<15$ $\mathrm{M} \Omega$ and seal resistance was $>1 \mathrm{G} \Omega$. $\beta$ cells were identified by their characteristic larger size $(>5.5 \mathrm{pF})$ and complete inactivation of the voltage-gated $\mathrm{Na}^{+}$-current at a holding potential of $-70 \mathrm{mV}$.

Membrane potential in intact islets was recorded in the perforated patch configuration as previously described (Gopel et al. 1999). Islets were kept in place using a wide-bore holding pipette. All cells were perifused at $32^{\circ} \mathrm{C}$ with a solution containing: $138 \mathrm{mM} \mathrm{NaCl}, 5.6 \mathrm{mM} \mathrm{KCl}, 2.6 \mathrm{mM} \mathrm{CaCl}_{2}, 1.2 \mathrm{mM} \mathrm{MgCl}_{2}$, and $5 \mathrm{mM}$ HEPES. The $\mathrm{pH}$ was adjusted to 7.4 with $\mathrm{NaOH}$. Access to the cell interior was established by addition of 0.24 $\mathrm{mg} / \mathrm{mL}$ of the pore-forming anti-fungal drug amphotericin $\mathrm{B}$ (Rae et al. 1991) to the pipette solution containing: $76 \mathrm{mM}$ $\mathrm{K}_{2} \mathrm{SO}_{4}, 10 \mathrm{mM} \mathrm{KCl}, 10 \mathrm{mM} \mathrm{NaCl}, 1 \mathrm{mM} \mathrm{MgCl}$, and $5 \mathrm{mM}$ Hepes. The $\mathrm{pH}$ was adjusted to 7.35 at $32^{\circ} \mathrm{C}$ using $\mathrm{CsOH}$. Perforation required a few minutes and the voltage clamp was considered satisfactory when the series resistance was $30 \mathrm{M} \Omega$ or lower.

\section{Calcium fluorimetry}

$\left[\mathrm{Ca}^{2+}\right]_{\mathrm{i}}$ was assessed in freshly isolated intact islets using a dual wavelength PTI system (PTI, Monmouth Junction) fitted on an inverted microscope. Islets were loaded with $3 \mu \mathrm{M}$ fura-2AM in the presence of $0.007 \% \mathrm{w} / \mathrm{v}$ pluronic acid (Invitrogen) for $25 \mathrm{~min}$ at $37^{\circ} \mathrm{C}$. Islets were held in place in the experimental chamber using a fire-polished borosilicate glass pipette. The chamber was superfused with a solution composed of $140 \mathrm{mM} \mathrm{NaCl}, 3.6 \mathrm{mM}$ $\mathrm{KCl}, 2 \mathrm{mM} \mathrm{NaHCO}, 0.5 \mathrm{mM} \mathrm{NaH}_{2} \mathrm{PO}_{4}, 0.5 \mathrm{mM} \mathrm{MgSO}_{4}, 5 \mathrm{mM}$ Hepes (pH 7.4 with $\mathrm{NaOH})$, and $2.6 \mathrm{mM} \mathrm{CaCl}_{2}$ preheated with an automatic temperature controller (TC 324B, Warner Instrument Corporation) to maintain a bath temperature of $37^{\circ} \mathrm{C}$. Glucose and tolbutamide were included in the extracellular medium as indicated. The fluorochrome was excited at 350 and 380 $\mathrm{nm}$. Emitted light was collected at $510 \mathrm{~nm}$. The F350/F380-ratio was determined at a frequency of $25 \mathrm{~Hz}$.

\section{Statistics}

Results are expressed as mean \pm standard error (SE), unless indicated differently. Statistical analysis was performed using Excel 2007 (Microsoft), SigmaStat 3.5 (Statcon), and SPSS 15 (SPSS). Equality of variances as well as normality was tested in all experiments. Significance of differences between data sets was assessed using Student's unpaired two-sided $t$-test or ANOVA in case of multiple groups. In case of nonequal variances and/or nonnormality, analysis was performed using the Mann-Whitney rank sum test (two groups) or the Kruskall-Wallis ANOVA (three or more groups). ANOVA analyses were followed by Dunnett, Dunn, Bonferroni, Student-Newman-Keuls, or Fisher LSD multicomparison (as indicated).

\section{Acknowledgments}

We thank all members of our laboratory for discussions. We are grateful to Pedro Herrera for providing the Rip2-Cre mice. We are particularly thankful to Markus Stoffel, Ian Frew, and Sreya 
Basu for critical reading of the manuscript. We also thank Sabine Uhles and Haiyan Wang for advice in islet perifusion. K.E. is supported by the Roche-CC-SPMD Diabetes Program. The groups of F.M.A. and P.R. are supported by the Wellcome Trust.

\section{References}

Ainscow, E.K., Zhao, C., and Rutter, G.A. 2000. Acute overexpression of lactate dehydrogenase-A perturbs $\beta$-cell mitochondrial metabolism and insulin secretion. Diabetes 49: $1149-1155$.

Ashcroft, S.J., Weerasinghe, L.C., Bassett, J.M., and Randle, P.J. 1972. The pentose cycle and insulin release in mouse pancreatic islets. Biochem. J. 126: 525-532.

Bouwens, L. and Rooman, I. 2005. Regulation of pancreatic $\beta$ cell mass. Physiol. Rev. 85: 1255-1270.

Brahimi-Horn, M.C., Chiche, J., and Pouyssegur, J. 2007. Hypoxia signalling controls metabolic demand. Curr. Opin. Cell Biol. 19: 223-229.

Coppack, S.W. 2001. Pro-inflammatory cytokines and adipose tissue. Proc. Nutr. Soc. 60: 349-356.

Cramer, T., Yamanishi, Y., Clausen, B.E., Forster, I., Pawlinski, R., Mackman, N., Haase, V.H., Jaenisch, R., Corr, M., Nizet, V., et al. 2003. HIF- $1 \alpha$ is essential for myeloid cell-mediated inflammation. Cell 112: 645-657.

De Boer, R.A., Pinto, Y.M., and Van Veldhuisen, D.J. 2003. The imbalance between oxygen demand and supply as a potential mechanism in the pathophysiology of heart failure: The role of microvascular growth and abnormalities. Microcirculation 10: 113-126.

Fantin, V.R., St-Pierre, J., and Leder, P. 2006. Attenuation of LDH-A expression uncovers a link between glycolysis, mitochondrial physiology, and tumor maintenance. Cancer Cell 9: 425-434.

Frew, I.J., Thoma, C.R., Georgiev, S., Minola, A., Hitz, M., Montani, M., Moch, H., and Krek, W. 2008. pVHL and PTEN tumour suppressor proteins cooperatively suppress kidney cyst formation. EMBO J. 27: 1747-1757.

Gopel, S.O., Kanno, T., Barg, S., Eliasson, L., Galvanovskis, J., Renstrom, E., and Rorsman, P. 1999. Activation of $\mathrm{Ca}(2+)$ dependent $\mathrm{K}(+)$ channels contributes to rhythmic firing of action potentials in mouse pancreatic $\beta$ cells. J. Gen. Physiol. 114: 759-770.

Gunton, J.E., Kulkarni, R.N., Yim, S., Okada, T., Hawthorne, W.J., Tseng, Y.H., Roberson, R.S., Ricordi, C., O'Connell, P.J., Gonzalez, F.J., et al. 2005. Loss of ARNT/HIF1 $\beta$ mediates altered gene expression and pancreatic-islet dysfunction in human type 2 diabetes. Cell 122: 337-349.

Haase, V.H., Glickman, J.N., Socolovsky, M., and Jaenisch, R. 2001. Vascular tumors in livers with targeted inactivation of the von Hippel-Lindau tumor suppressor. Proc. Nat1. Acad. Sci. 98: 1583-1588.

Hellwig-Burgel, T., Stiehl, D.P., Wagner, A.E., Metzen, E., and Jelkmann, W. 2005. Review: Hypoxia-inducible factor-1 (HIF-1): A novel transcription factor in immune reactions. J. Interferon Cytokine Res. 25: 297-310.

Hergovich, A., Lisztwan, J., Barry, R., Ballschmieter, P., and Krek, W. 2003. Regulation of microtubule stability by the von Hippel-Lindau tumour suppressor protein pVHL. Nat. Cell Biol. 5: 64-70.

Herrera, P.L. 2000. Adult insulin- and glucagon-producing cells differentiate from two independent cell lineages. Development 127: 2317-2322.

Hu, C.J., Wang, L.Y., Chodosh, L.A., Keith, B., and Simon, M.C.
2003. Differential roles of hypoxia-inducible factor $1 \alpha$ (HIF$1 \alpha)$ and HIF- $2 \alpha$ in hypoxic gene regulation. Mol. Cell. Biol. 23: 9361-9374.

Ishihara, H., Wang, H., Drewes, L.R., and Wollheim, C.B. 1999. Overexpression of monocarboxylate transporter and lactate dehydrogenase alters insulin secretory responses to pyruvate and lactate in $\beta$ cells. J. Clin. Invest. 104: 1621-1629.

Ivarsson, R., Quintens, R., Dejonghe, S., and Tsukamoto, K., in 't Veld, P., Renstrom, E., and Schuit, F.C. 2005. Redox control of exocytosis: Regulatory role of NADPH, thioredoxin, and glutaredoxin. Diabetes 54: 2132-2142.

Kahn, S.E., Hull, R.L., and Utzschneider, K.M. 2006. Mechanisms linking obesity to insulin resistance and type 2 diabetes. Nature 444: 840-846.

Kennedy, E.D., Maechler, P., and Wollheim, C.B. 1998. Effects of depletion of mitochondrial DNA in metabolism secretion coupling in INS-1 cells. Diabetes 47: 374-380.

Khan, A., Ling, Z.C., and Landau, B.R. 1996. Quantifying the carboxylation of pyruvate in pancreatic islets. J. Biol. Chem. 271: 2539-2542.

Kibbey, R.G., Pongratz, R.L., Romanelli, A.J., Wollheim, C.B., Cline, G.W., and Shulman, G.I. 2007. Mitochondrial GTP regulates glucose-stimulated insulin secretion. Cell Metab. 5: 253-264.

Kim, J.W., Tchernyshyov, I., Semenza, G.L., and Dang, C.V. 2006. HIF-1-mediated expression of pyruvate dehydrogenase kinase: A metabolic switch required for cellular adaptation to hypoxia. Cell Metab. 3: 177-185.

Lammert, E., Gu, G., McLaughlin, M., Brown, D., Brekken, R., Murtaugh, L.C., Gerber, H.P., Ferrara, N., and Melton, D.A. 2003. Role of VEGF-A in vascularization of pancreatic islets. Curr. Biol. 13: 1070-1074.

Levitsky, L.L., Zheng, Q., Mink, K., and Rhoads, D.B. 1994. GLUT-1 and GLUT-2 mRNA, protein, and glucose transporter activity in cultured fetal and adult hepatocytes. Am. J. Physiol. 267: E88-E94.

Li, X., Zhang, L., Meshinchi, S., Dias-Leme, C., Raffin, D., Johnson, J.D., Treutelaar, M.K., and Burant, C.F. 2006. Islet microvasculature in islet hyperplasia and failure in a model of type 2 diabetes. Diabetes 55: 2965-2973.

Lu, D., Mulder, H., Zhao, P., Burgess, S.C., Jensen, M.V., Kamzolova, S., Newgard, C.B., and Sherry, A.D. 2002. 13C NMR isotopomer analysis reveals a connection between pyruvate cycling and glucose-stimulated insulin secretion (GSIS). Proc. Nat1. Acad. Sci. 99: 2708-2713.

Lum, J.J., Bui, T., Gruber, M., Gordan, J.D., DeBerardinis, R.J., Covello, K.L., Simon, M.C., and Thompson, C.B. 2007. The transcription factor HIF- $1 \alpha$ plays a critical role in the growth factor-dependent regulation of both aerobic and anaerobic glycolysis. Genes \& Dev. 21: 1037-1049.

MacDonald, M.J., Fahien, L.A., Brown, L.J., Hasan, N.M., Buss, J.D., and Kendrick, M.A. 2005. Perspective: Emerging evidence for signaling roles of mitochondrial anaplerotic products in insulin secretion. Am. J. Physiol. Endocrinol. Metab. 288: E1-E15. doi: 10.1152/ajpendo.00218.2004.

Maechler, P. and Wollheim, C.B. 2001. Mitochondrial function in normal and diabetic $\beta$-cells. Nature 414: 807-812.

Marti, H.H. 2005. Angiogenesis-a self-adapting principle in hypoxia. EXS 2005: 163-180.

Nicholls, L.I., Ainscow, E.K., and Rutter, G.A. 2002. Glucosestimulated insulin secretion does not require activation of pyruvate dehydrogenase: Impact of adenovirus-mediated overexpression of PDH kinase and PDH phosphate phosphatase in pancreatic islets. Biochem. Biophys. Res. Commun. 291: 1081-1088.

Noel, L.E. and Newgard, C.B. 1997. Structural domains that 


\section{Zehetner et al.}

contribute to substrate specificity in facilitated glucose transporters are distinct from those involved in kinetic function: Studies with GLUT-1/GLUT-2 chimeras. Biochemistry 36: 5465-5475.

Papandreou, I., Cairns, R.A., Fontana, L., Lim, A.L., and Denko, N.C. 2006. HIF-1 mediates adaptation to hypoxia by actively downregulating mitochondrial oxygen consumption. Cell Metab. 3: 187-197.

Prentki, M. and Nolan, C.J. 2006. Islet $\beta$ cell failure in type 2 diabetes. J. Clin. Invest. 116: 1802-1812.

Rae, J., Cooper, K., Gates, P., and Watsky, M. 1991. Low access resistance perforated patch recordings using amphotericin $\mathrm{B}$. J. Neurosci. Methods 37: 15-26.

Rankin, E.B., Rha, J., Unger, T.L., Wu, C.H., Shutt, H.P., Johnson, R.S., Simon, M.C., Keith, B., and Haase, V.H. 2008. Hypoxia-inducible factor-2 regulates vascular tumorigenesis in mice. Oncogene 27: 5354-5358.

Rhodes, C.J. 2005. Type 2 diabetes-a matter of $\beta$-cell life and death? Science 307: 380-384.

Rius, J., Guma, M., Schachtrup, C., Akassoglou, K., Zinkernagel, A.S., Nizet, V., Johnson, R.S., Haddad, G.G., and Karin, M. 2008. NF-кB links innate immunity to the hypoxic response through transcriptional regulation of HIF-1 $\alpha$. Nature 453: $807-811$.

Schipani, E., Ryan, H.E., Didrickson, S., Kobayashi, T., Knight, M., and Johnson, R.S. 2001. Hypoxia in cartilage: HIF-1 $\alpha$ is essential for chondrocyte growth arrest and survival. Genes \& Dev. 15: 2865-2876.

Schofield, C.J. and Ratcliffe, P.J. 2004. Oxygen sensing by HIF hydroxylases. Nat. Rev. Mol. Cell Biol. 5: 343-354.

Schuit, F., De Vos, A., Farfari, S., Moens, K., Pipeleers, D., Brun, T., and Prentki, M. 1997. Metabolic fate of glucose in purified islet cells. Glucose-regulated anaplerosis in $\beta$ cells. J. Biol. Chem. 272: 18572-18579.

Semenza, G.L. 2001. HIF-1 and mechanisms of hypoxia sensing. Curr. Opin. Cell Biol. 13: 167-171.

Shaw, R.J. 2006. Glucose metabolism and cancer. Curr. Opin. Cell Biol. 18: 598-608.

Thoma, C.R., Frew, I.J., Hoerner, C.R., Montani, M., Moch, H., and Krek, W. 2007. pVHL and GSK3 $\beta$ are components of a primary cilium-maintenance signalling network. Nat. Cell Biol. 9: 588-595.

Tsuruzoe, K., Araki, E., Furukawa, N., Shirotani, T., Matsumoto, K., Kaneko, K., Motoshima, H., Yoshizato, K., Shirakami, A., Kishikawa, H., et al. 1998. Creation and characterization of a mitochondrial DNA-depleted pancreatic $\beta$ cell line: Impaired insulin secretion induced by glucose, leucine, and sulfonylureas. Diabetes 47: 621-631.

Van Assche, F.A., Aerts, L., and De Prins, F. 1978. A morphological study of the endocrine pancreas in human pregnancy. Br. J. Obstet. Gynaecol. 85: 818-820.

Yaney, G.C. and Corkey, B.E. 2003. Fatty acid metabolism and insulin secretion in pancreatic $\beta$ cells. Diabetologia 46: 1297-1312. 


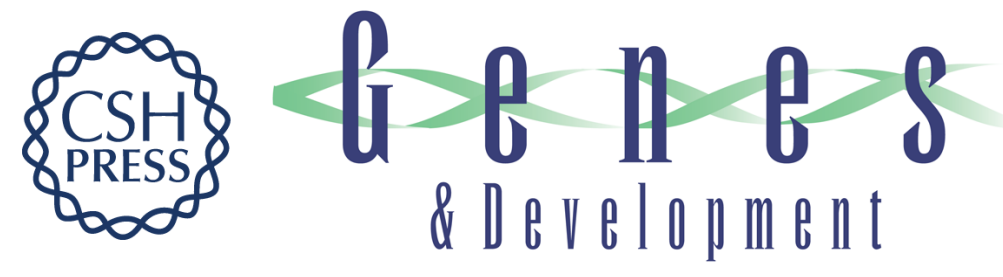

\section{pVHL is a regulator of glucose metabolism and insulin secretion in pancreatic $\beta$ cells}

Jens Zehetner, Carsten Danzer, Stephan Collins, et al.

Genes Dev. 2008, 22:

Access the most recent version at doi:10.1101/gad.496908

Supplemental http://genesdev.cshlp.org/content/suppl/2008/11/24/22.22.3135.DC1
Material

References This article cites 48 articles, 16 of which can be accessed free at:

http://genesdev.cshlp.org/content/22/22/3135.full.html\#ref-list-1

License

Email Alerting

Receive free email alerts when new articles cite this article - sign up in the box at the top

Service

right corner of the article or click here.

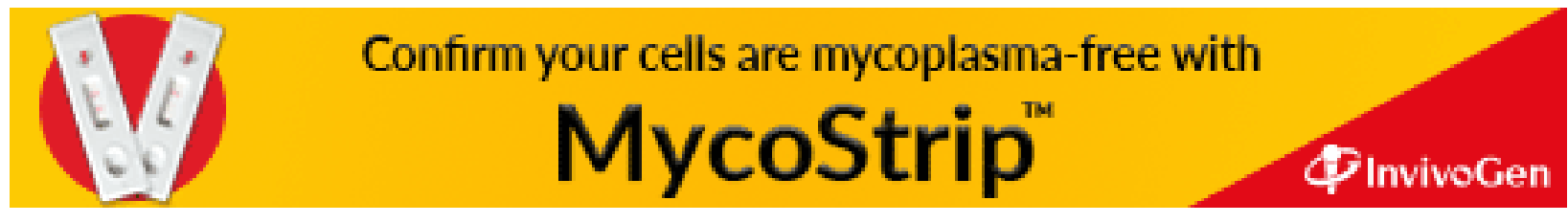

